\title{
PEMBANGKIT LISTRIK ELECTRON POWER INVERTER (EPI) DENGAN MEMANFAATKAN BUAH BELIMBING WULUH DAN KULIT PISANG
}

\author{
Wiwik Purwati Widyaningsih, Margana \\ Jurusan Teknik Mesin, Politeknik Negeri Semarang \\ Jl. Prof. H. Sudarto, S.H., Tembalang, Kotak Pos 6199/SMS, Semarang 50329 \\ Telp. 7473417, 7466420 (Hunting), fax. 7472396 \\ Abstrak
}

Aki merupakan alat yang dapat menyimpan energi listrik dalam bentuk energi kimia. Aki banyak digunakan pada kendaraan bermotor dan untuk menyalakan lampu rumah saat terjadi pemadaman. Komponen aki terdiri dari elektroda dan elektrolit. Cairan elektrolit aki yang digunakan yaitu cairan asam sulfat $\left(\mathrm{H}_{2} \mathrm{SO}_{4}\right)$ atau biasa disebut aki zuur. Penelitian ini bertujuan untuk memanfaatkan campuran buah belimbing wuluh dengan kulit pisang sehingga dapat dijadikan pengganti alternatif elektrolit yang ramah lingkungan. Metode yang digunakan adalah menentukan perbandingan persentase volume dari buah belimbing wuluh dengan kulit pisang sehingga dapat menghasilkan tegangan DC dan arus yang maksimal kemudian diubah menjadi tegangan AC dengan menggunakan inverter. Perbandingan campuran buah belimbing wuluh dan kulit pisang dengan perbandingan 90\%: 10\%; 80\%: 20\%; $70 \%$ : 30\%. Aki dengan persentase buah belimbing wuluh dan kulit pisang 90\%: 10\% merupakan aki terbaik yang mempunyai ketahanan waktu selama 24 Jam dengan nilai tegangan sebelum dibebani yaitu 12,1 Volt, tegangan setelah dibebani yaitu 7,8 Volt dan arusnya sebesar 0,019 Ampere. Sedangkan 5 box aki menggunakan inverter dengan persentase 90\%: 10\% menghasilkan gelombang AC dengan tegangan 1,8 Volt ketika dibebani menjadi 1,4 Volt dengan arus listrik 0,0186 Ampere ketika beban 75 Ohm.

Kata Kunci: Aki, Belimbing Wuluh, Kulit pisang, Inverter

\section{- PENDAhUluan}

Aki adalah alat yang digunakan untuk menyimpan energi dalam bentuk kimia. Apabila aki digunakan terus menerus akan habis sehingga perlu dilakukan pengisian ulang (charging) terlebih dahulu. Dalam jangka waktu kurang lebih satu tahun biasanya kerja aki mulai tidak maksimal.

Asam sulfat $\left(\mathrm{H}_{2} \mathrm{SO}_{4}\right)$ atau biasa disebut aki zuur memiliki sifat yang berbahaya karena jika terkena kulit manusia akan terasa gatal-gatal dan panas, jika terkena kain akan berlubang, jika dibuang akan mengakibatkan lingkungan tercemar, sedangkan jika terkena besi akan mengakibatkan besi menjadi berkarat karena aki zuur ini mengandung asam sulfat.

Belimbing wuluh mengandung asam format $(\mathrm{HCOOH})$ dengan kadar keasaman yang tinggi dengan nilai pH 2 (Orwa dkk, 2009 dalam wikanta) dan kulit pisang mengandung asam sitrat $(\mathrm{CH} 3 \mathrm{COOH})$ dengan nilai $\mathrm{pH}$ pada buah pisang yang masih berwarna hijau yaitu 5,02 - 5,6 dan pada pisang matang berkisar antara 4,2 - 4,75. (Pujimulyani, 2009). Dengan tingkat keasaman yang dihasilkan dari cairan buah belimbing wuluh dan kulit pisang, maka dapat dijadikan energi alternatif yang digunakan sebagai pengganti cairan elektrolit asam sulfat $\left(\mathrm{H}_{2} \mathrm{SO}_{4}\right)$ pada aki. Elektrolit dalam aki bersifat asam, sehingga buah yang bersifat asam dapat menjadi elektrolit (Sutikno, 2008).

Berdasarkan kebutuhan tegangan AC di Indonesia, maka melalui Tugas Akhir ini diharapkan pemanfaatan buah belimbing wuluh dan kulit pisang sebagai media sumber energi alternatif dengan penambahan inverter.

\section{Perumusan Masalah}

Rumusan masalah penelitian pemanfaatan buah belimbing wuluh dan kulit pisang sebagai pengganti akizur $\left(\mathrm{H}_{2} \mathrm{SO}_{4}\right)$ pada aki dengan penambahan inverter untuk energi alternatif adalah Berapakah persentase volume dari buah belimbing wuluh dan kulit pisang sebagai pengganti akizur yang baik untuk menghasilkan tegangan?

\section{- Metode penelitian}

Dalam program penelitian ini metode yang digunakan adalah dengan melakukan kegiatan studi litelatur yang terkait tentang pengujian kami, serta melakukan pengujian terhadap aki kami. Untuk mendapatkan pemahaman yang komprehensif, langkahlangkah penelitian diuraikan seperti berikut. Persiapan langkah ini dilakukan berdasarkan objek penelitian meliputi jurnal-jurnal dan artikel dengan cara menelusuri di perpustakaan dan internet. Setelah melakukan studi pustaka maka didapatkan cairan yang dapat menghasilkan energi listrik dan alat elektronik yang sesuai untuk mengubah tegangan AC ke DC dengan arus yang kecil. Aki konvensional biasanya menggunakan elektroda Timbal $(\mathrm{Pb})$ dan Timbal dioksida $\left(\mathrm{PbO}_{2}\right)$ dengan elektrolit Asam Sulfat $\left(\mathrm{H}_{2} \mathrm{SO}_{4}\right)$. Pada pengujian ini kami menggunakan elektroda Seng (Zn) dan Tembaga $\mathrm{C} \mathrm{Cu})$ dengan elektrolit dari buah belimbing wuluh dan kulit pisang. Pengambilan data dilakukan dengan menggunakan persentase volume yang berbeda-beda yaitu $90 \%: 10 \%, 80 \%: 20 \%, 70 \%: 30 \%$ dengan 
menggunakan voltmeter untuk mengukur tegangan dan ampermeter untuk mengukur arus. Kemudian pengujian menggunakan inverter dengan

persentase volume belimbing wuluh dan kulit pisang yang baik. Parameter yang digunakan adalah tegangan aki, arus aki, tegangan input inverter, arus input inveter, tegangan output inverter, arus output inverter, lama waktu pengujian.

Kemudian mencatat parameter-parameter ke dalam tabel dan membuat analisa data, grafik dan kesimpulan. Tahap terakhir adalah menyusun laporan akhir dan artikel ilmiah.

\section{- HASIL DAN PEMBAHASAN}

Model casing aki yang kami gunakan untuk penelitian seperti gambar dibawah ini.

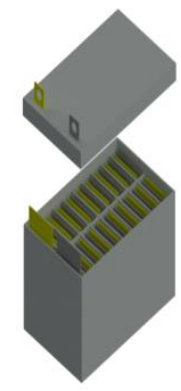

Gambar 1 Model Casing Aki untuk Larutan Belimbing Wuluh dan Kulit Pisang

Berikut ini adalah data hasil percobaan dan pengolahan data kami sajikan dalam bentuk table dan grafik.

Tabel 1. Data hasil pengukuran tanpa inverter

\begin{tabular}{|c|c|c|c|c|c|}
\hline $\begin{array}{c}\text { Arus.hours } \\
\text { (A.h) }\end{array}$ & \multicolumn{2}{|c|}{ Energi (Wh) } & \multicolumn{2}{|c|}{ Waktu menyala (menit) } \\
\hline & $\begin{array}{c}\text { Sebelum } \\
\text { Dibebani }\end{array}$ & $\begin{array}{c}\text { Setelah } \\
\text { Dibebani }\end{array}$ & $\begin{array}{c}\text { Terang } \\
\text { teori }\end{array}$ & $\begin{array}{c}\text { Terang } \\
\text { praktik }\end{array}$ & Redup \\
\hline- & - & - & - & - & - \\
\hline 0,456 & 0 & 3,55 & 42,6 & 30 & 660 \\
\hline 0,342 & 0 & 2,49 & 29,88 & 15 & 540 \\
\hline
\end{tabular}

Didapatkan kapasitas dan daya aki melalui perhitungan dan waktu efektif penyalaan lampu pada tabel dibawah

Tabel 2. Data Hasil Pengukuran menggunakan Inverter

\begin{tabular}{|c|c|c|c|c|c|c|c|c|c|c|}
\hline \multirow{2}{*}{\begin{tabular}{|c} 
Persentase \\
Belimbing \\
Wuluh: \\
Kulit \\
Pisang \\
\end{tabular}} & \multicolumn{2}{|c|}{$\begin{array}{l}\text { Tegangan Aki } \\
\text { (VDC) }\end{array}$} & \multicolumn{2}{|c|}{$\begin{array}{l}\text { Tegangan Inverter } \\
\text { (VAC) }\end{array}$} & \multirow[t]{2}{*}{$\begin{array}{r}\text { Waklu } \\
\text { (Jam) }\end{array}$} & \multicolumn{2}{|c|}{ Anus (A) } & \multicolumn{2}{|c|}{ Daya (IV) } & \multirow{2}{*}{$\begin{array}{c}\text { Efisiensi } \\
(\%)\end{array}$} \\
\hline & $\begin{array}{l}\text { Scbclum } \\
\text { Dibcbani }\end{array}$ & $\begin{array}{c}\text { Sctelah } \\
\text { Dibcbani }\end{array}$ & $\begin{array}{l}\text { Scbclum } \\
\text { Dibcbani }\end{array}$ & $\begin{array}{l}\text { Sctelah } \\
\text { Dibbtani } \\
\end{array}$ & & $\begin{array}{l}\text { Pada } \\
\text { input } \\
\text { (II) }\end{array}$ & \begin{tabular}{|c|} 
Pada \\
Output \\
(12) \\
\end{tabular} & $\begin{array}{c}\text { Pada Input } \\
\text { (PI) }\end{array}$ & $\begin{array}{l}\text { Pada } \\
\text { Output } \\
\text { (P2) }\end{array}$ & \\
\hline \multirow{17}{*}{ 90\%:10\% } & 12 & 7,8 & 1,8 & 1,4 & $15: 00$ & 0,08 & 0,019 & 0,62 & 0,026 & 4,2 \\
\hline & 11,5 & 7,6 & 1,8 & 1,35 & $16: 00$ & 0,75 & 0,018 & 0,57 & 0,024 & 4,4 \\
\hline & 11 & 6,6 & 1,6 & 1,3 & 17:00 & 0,072 & 0,018 & 0,47 & 0,023 & 4,9 \\
\hline & 10 & 5,4 & 1,6 & 1,25 & 18:00 & 0,06 & 0,017 & 0,32 & 0,021 & 6,5 \\
\hline & 9,5 & 4,2 & 1,4 & 1,2 & 19:00 & 0,05 & 0,016 & 0,21 & 0,019 & 9,1 \\
\hline & 9,3 & 4,2 & 1,4 & 1,16 & $20: 00$ & 0,045 & 0,015 & 0,18 & 0,017 & 9,2 \\
\hline & 9 & 4,1 & 1,3 & 1,14 & $21: 00$ & 0,04 & 0,014 & 0,16 & 0,015 & 9,7 \\
\hline & 8.5 & 4,1 & 1,3 & 1,12 & $22: 00$ & 0,035 & 0,012 & 0,14 & 0,013 & 9,3 \\
\hline & 8,2 & 4 & 1,2 & 1 & $23: 00$ & 0,03 & 0,013 & 0,12 & 0,01 & 8,3 \\
\hline & 8 & 3,8 & 0 & 0 & 0:00:00 & 0,03 & 0 & 0,11 & 0 & 0 \\
\hline & 7,8 & 3,6 & 0 & 0 & 1:00 & 0,028 & 0 & 0,1 & 0 & 0 \\
\hline & 7,6 & 3,4 & 0 & 0 & $2: 00$ & 0,026 & 0 & 0,09 & 0 & 0 \\
\hline & 7,5 & 3,4 & 0 & 0 & $3: 00$ & 0,025 & 0 & 0,08 & 0 & 0 \\
\hline & 6 & 3 & 0 & 0 & $4: 00$ & 0,02 & 0 & 0,06 & 0 & 0 \\
\hline & 5 & 2 & 0 & 0 & 5:00 & 0,015 & 0 & 0,03 & 0 & 0 \\
\hline & 4,4 & 1 & 0 & 0 & $6: 00$ & 0,013 & 0 & 0,01 & 0 & 0 \\
\hline & 3 & 0 & 0 & 0 & 7:00 & 0 & 0 & 0 & 0 & 0 \\
\hline
\end{tabular}

\begin{tabular}{|c|c|c|c|}
\hline \multirow{2}{*}{$\begin{array}{l}\text { Persentase } \\
\text { volume } \\
\text { belimbing } \\
\text { wuluh : kulit } \\
\text { pisang }\end{array}$} & \multicolumn{2}{|c|}{ Daya (W) } & \multirow{2}{*}{$\begin{array}{c}\text { Efisiensi } \\
(\%)\end{array}$} \\
\hline & $\begin{array}{l}\text { Pada input } \\
\text { (P1) }\end{array}$ & $\begin{array}{c}\text { Pada output } \\
\text { (P2) }\end{array}$ & \\
\hline \multirow{17}{*}{$90 \%: 10 \%$} & 0,62 & 0,026 & 4,2 \\
\hline & 0,57 & 0,024 & 4,4 \\
\hline & 0,47 & 0,023 & 4,9 \\
\hline & 0,32 & 0,021 & 6,5 \\
\hline & 0,21 & 0,019 & 9,1 \\
\hline & 0,18 & 0,017 & 9,2 \\
\hline & 0,16 & 0,015 & 9,7 \\
\hline & 0,14 & 0,013 & 9,3 \\
\hline & 0,12 & 0,01 & 8,3 \\
\hline & 0,11 & 0 & 0 \\
\hline & 0,1 & 0 & 0 \\
\hline & 0,09 & 0 & 0 \\
\hline & 0,08 & 0 & 0 \\
\hline & 0,06 & 0 & 0 \\
\hline & 0,03 & 0 & 0 \\
\hline & 0,01 & 0 & 0 \\
\hline & 0 & 0 & 0 \\
\hline
\end{tabular}


Didapatkan daya pada aki dan daya output inverter melalui perhitungan dan waktu efektif penyalaan lampu pada tabel dibawah

Data perhitungan kapasitas aki tanpa inverter dengan variasi persentase volume $90 \%: 10 \%$.

- Waktu pengamatan

$$
(\mathrm{t})=24 \mathrm{jam}
$$

- $\quad$ Tegangan sebelum dibebani $(\mathrm{V})=12,1$ Volt

- Tegangan setelah dibebani

$$
\left(\mathrm{V}^{\prime}{ }^{\prime}\right)=7,8 \text { Volt }
$$

- $\quad$ Arus listrik

$$
\text { - }=0,019 \text { Ampere }
$$

Energi setelah dibebani:

$$
\begin{aligned}
\mathrm{W}_{1} & =\mathrm{V}_{1} \cdot \mathrm{I} \cdot \mathrm{t} \\
& =7,8 \cdot 0,019 \cdot 24 \\
& =3,55 \mathrm{Wh}
\end{aligned}
$$

Perhitungan lama nyala lampu terang:

$$
\begin{aligned}
\mathrm{t} \quad & () .() \\
& =() \\
& =() .60 \text { menit } \\
& =42,6 \text { menit } \\
& \text { Data perhitungan setelah penambahan inverter }
\end{aligned}
$$
pada satu jam pertama.

- Waktu sampai aki habis

$$
\mathrm{t} 1=16 \mathrm{jam}
$$

- Waktu sampai teganagn inverter nol

$$
\mathrm{t} 2=9 \mathrm{jam}
$$

- Tegangan aki

$$
\mathrm{V} 1=7,8 \text { Volt }
$$

- Arus pada input

$$
\text { I1 = 0,08 Ampere }
$$

- Tegangan pada inverter

$$
\text { V2 }=1,4 \text { Volt }
$$

- Arus pada inverter

$$
\text { I2 = 0,019 Ampere }
$$

Waktu ketahanan aki dalam satuan jam

$\mathrm{t}=$ waktu awal pengujian sampai waktu akhir

$$
\text { pengujian (jam) }
$$$$
=16 \mathrm{jam}
$$

Muatan Input Inverter ( $Q_{\text {in }}$

$$
\begin{aligned}
Q_{\text {in }} & =\mathrm{I}_{1} \cdot \mathrm{t}_{1} \\
& =0,08 \cdot 16 \\
& =1,28 \mathrm{Ah}
\end{aligned}
$$

Daya Input Inverter $\left(\mathrm{P}_{\text {in }}\right)$

$$
\begin{aligned}
\mathrm{P}_{\text {in }} & =\mathrm{V}_{1} \cdot \mathrm{I}_{1} \\
& =7,8 \cdot 0,08 \\
& =0,62 \mathrm{~W}
\end{aligned}
$$

Energi Input Inverter $\left(\mathrm{W}_{\text {in }}\right)$

$$
\begin{aligned}
\mathrm{W}_{\text {in }} & =\mathrm{P}_{1} . \mathrm{t}_{1} \\
& =0,62.16 \\
& =9,98 \mathrm{Wh}
\end{aligned}
$$

Muatan Output Inverter ( $\left.Q_{\text {out }}\right)$ Pengujian pada waktu 9 jam

$$
\begin{aligned}
\mathrm{Q}_{\text {out }} & =\mathrm{I}_{2} \cdot \mathrm{t}_{2} \\
& =0,019 \cdot 9 \\
& =0,171 \mathrm{Ah}
\end{aligned}
$$

Daya output Inverter $\left(\mathrm{P}_{\text {out }}\right)$

$$
\begin{aligned}
\mathrm{P}_{\text {out }} \quad=\mathrm{V}_{2} \cdot \mathrm{I}_{2} \cdot \operatorname{Cos} \varphi \\
=1,4 \cdot 0,019 \cdot 1 \\
=0,026 \mathrm{~W}
\end{aligned}
$$

$\operatorname{Cos} \varphi$ dianggap 1 karena beban resistif

Energi Output Inverter $\left(\mathrm{E}_{\text {out }}\right)$

$$
\begin{aligned}
\mathrm{E}_{\text {out }} & =\mathrm{P}_{2} \cdot \mathrm{t}_{2} \\
& =0,026 \cdot 9 \\
& =0,234 \mathrm{Wh}
\end{aligned}
$$

Effisiensi Inverter

$$
=4,2 \%
$$

Berikut ini adalah karakterisitik hubungan tegangan dengan waktu pada pemakaian aki.

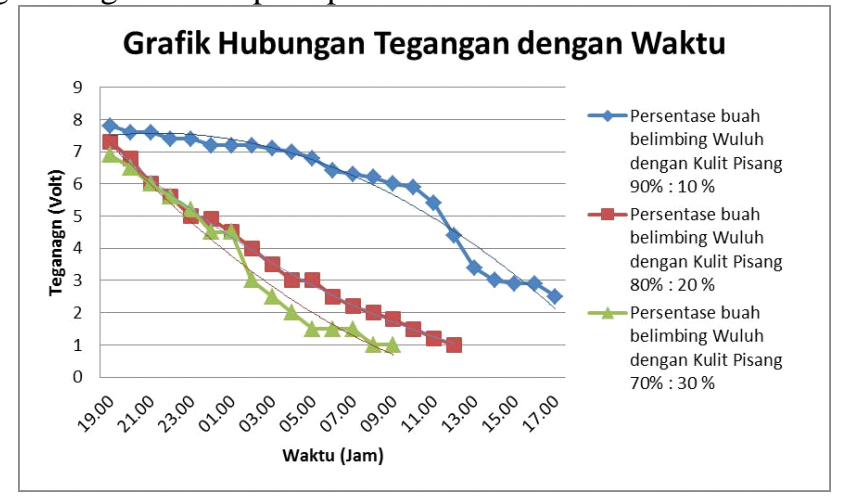

Gambar 2 Grafik Hubungan Tegangan dengan Waktu

Tiap Persentase Belimbing Wuluh : Kulit Pisang

Grafik hubungan antara tegangan terhadap waktu pada gambar 4.1, diperoleh dari data hasil pengujian pada 2 aki dengan persentase belimbing wuluh dan kulit pisang sebesar 90\%: 10\%, 80\%: $20 \%$, dan $70 \%: 30 \%$. Persentase cairan belimbing wuluh dan kulit pisang $90 \%$ : $10 \%$ pada saat dibebani lampu dengan daya 5 Watt dan tegangan 12 VDC menghasilkan nilai tegangan terbaik yaitu 7,8 Volt. Sedangkan nilai tegangan persentase belimbing wuluh dan kulit pisang $80 \%: 20 \%$, dan $70 \%$ : $30 \%$ setelah dibebani adalah 7,3 V dan 6,9 V. Hal ini disebabkan oleh transfer elektron oleh ion elektrolit persentase belimbing wuluh dan kulit pisang 90\%:10\% lebih baik. Nilai tegangan setiap percobaan semakin menurun setiap jam nya lebih dari $0,4 \mathrm{~V}$ dalam kurun waktu 12 jam, jika penurunan lebih dari $0,4 \mathrm{~V}$, maka hal tersebut mengindikasikan tahanan yang tinggi atau sambungan yang kotor atau longgar.

Berikut ini adalah karakterisitik hubungan arus dengan waktu pada pemakaian aki. 


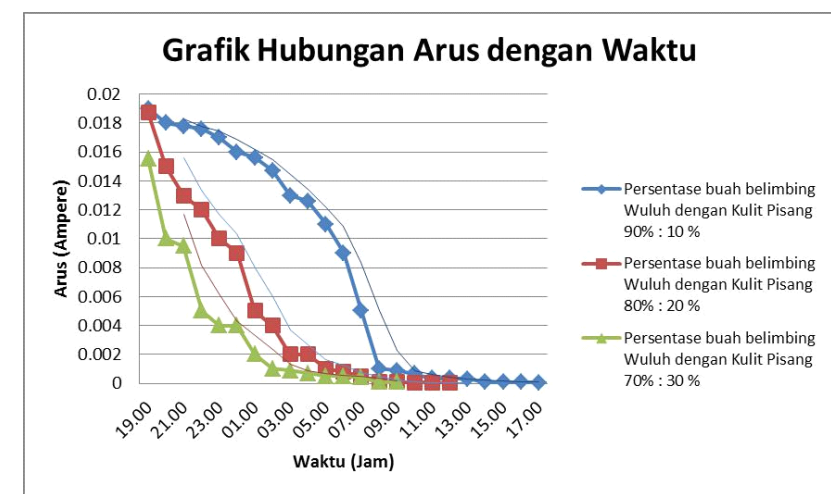

Gambar 3 Grafik Hubungan Arus dengan Waktu Tiap Persentase Belimbing Wuluh : Kulit Pisang

Grafik hubungan antara arus terhadap waktu pada gambar 4.1, diperoleh dari data hasil pengujian pada 2 aki dengan persentase belimbing wuluh dan kulit pisang sebesar $90 \%$ : $10 \%, 80 \%$ : $20 \%$, dan $70 \%: 30 \%$. Persentase cairan belimbing wuluh dan kulit pisang $90 \%$ : $10 \%$ dibebani lampu $5 \mathrm{~W}, 12$ VDC menghasilkan nilai arus terbaik yaitu $19 \mathrm{~mA}$. Sedangkan nilai tegangan persentase belimbing wuluh dan kulit pisang $80 \%: 20 \%$, dan $70 \%$ : $30 \%$ setelah dibebani adalah $18 \mathrm{~mA}$ dan 15,5 mA. Hal ini disebabkan oleh transfer elektron oleh ion elektrolit persentase belimbing wuluh dan kulit pisang $90 \%$ : 10\% lebih baik. Nilai arus turun drastis setiap percobaan hal ini disebabkan oleh nilai beban yang tinggi dan nilai arus yang dihasilkan kecil setiap percobaan persentase belimbing wuluh dan kulit pisang 90\%: 10\%, $80 \%$ : $20 \%$, dan $70 \%: 30 \%$ sebesar 1,9 mA, $18 \mathrm{~mA}$ dan 15,5 mA tidak memenuhi standart sebesar 0,42 A. pemakaian aki.

Berikut ini adalah waktu penyalaan lampu pada

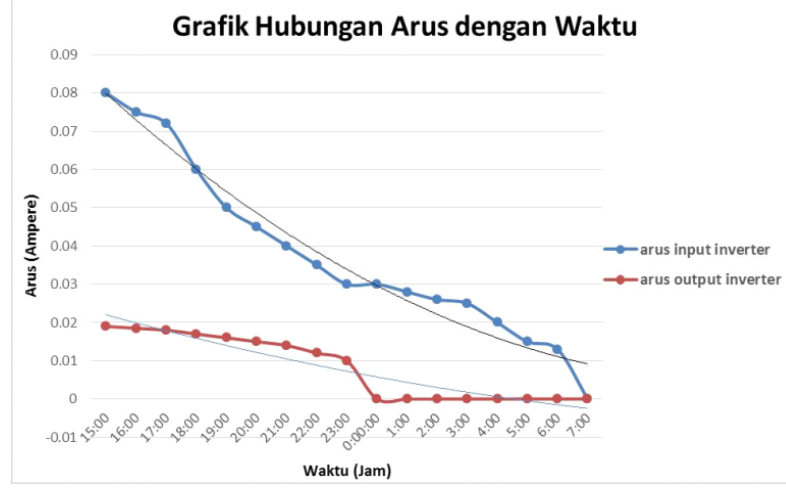

Gambar 4 Grafik Hubungan Nyala lampu dengan Waktu Tiap Persentase Belimbing Wuluh : Kulit Pisang.

Grafik hubungan antara nyala lampu terhadap waktu tiap persentase pada gambar 4.3, diperoleh dari data hasil pengujian 2 aki dengan persentase buah belimbing wuluh dan kulit pisang 90\%: 10\%, 80\%: 20\%, dan 70\%:30\%. Persentase cairan buah belimbing wuluh dan kulit pisang sebesar 90\% : 10\% pada saat dibebani lampu 5 W, 12
VDC menghasilkan periode waktu lampu menyala terang terbaik selama 30 menit dan 660 menit menyala redup. Sedangkan lama nyala lampu dengan persentase buah belimbing wuluh dan kulit pisang $80 \%$ : 20\%, dan $70 \%$ : $30 \%$ adalah 15 menit menyala terang, 540 menyala redup dan 8 menit menyala terang, 300 menit menyala redup. Ketidakakuratan nilai lama lampu menyala terang antara perhitungan setiap percobaan persentase buah belimbing wuluh dan kulit pisang 90\%:10\%, 80\%:20\%, dan $70 \%$ : 30\%, sebesar 42.6 menit, 29.88 menit dan 20.53 menit dengan praktik adalah rugi-rugi daya ntara lain cairan elektrolit dari buah yang mengalami perubahan, elektroda dalam cairan mengalami perubahan, elektrolit menguap, sebagian elektroda tidak tercelup elektrolit.

Berikut ini adalah karakterisitik hubungan tegangan dengan waktu pada pemakaian penambahan inverter.

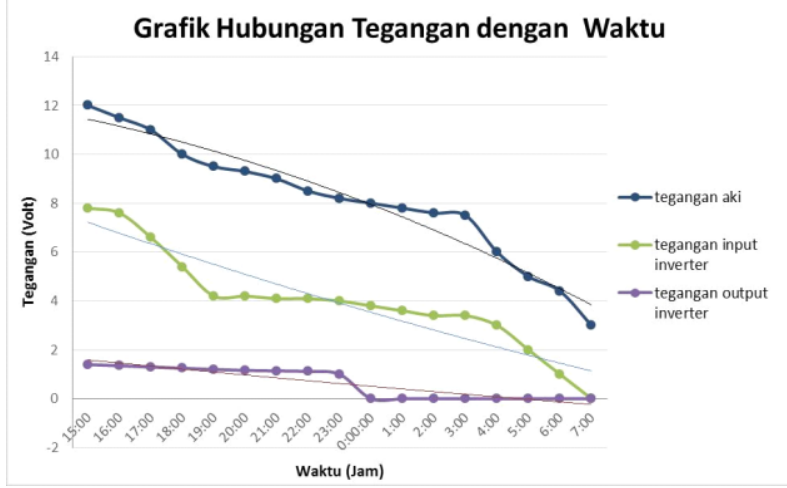

Gambar 5 Grafik Hubungan Tegangan dengan Waktu pada Persentase Volume Belimbing Wuluh : Kulit Pisang (90\%: 10\%)

Berikut ini adalah karakterisitik hubungan efisiensi dengan waktu pada pemakaian penambahan inverter.

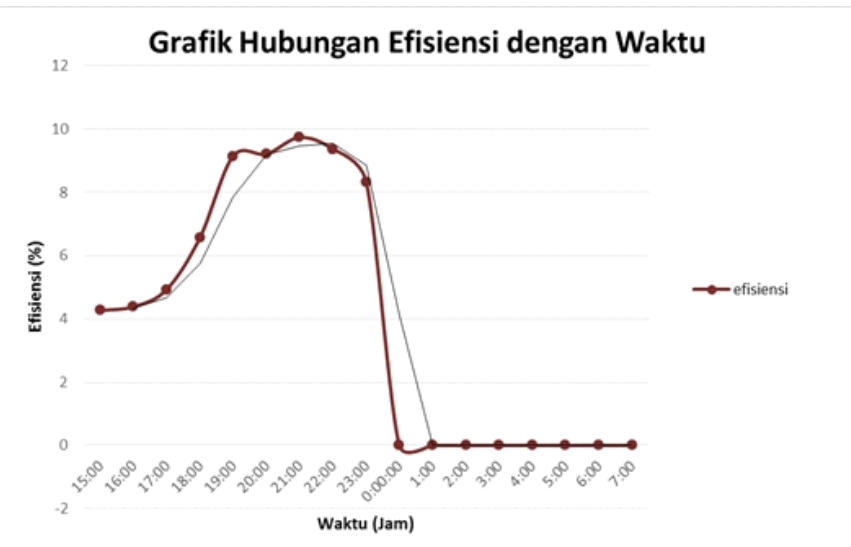

Gambar 6 Grafik Hubungan Efisiensi dengan Waktu pada Persentase Volume Belimbing Wuluh : Kulit Pisang (90\%: 10\%)

Grafik hubungan antara arus input inverter, arus output inverter, tegangan aki, tegangan input inverter, 
tegangan output inverter, energi perjamnya input inverter, energi perjamnya output inverter, efisiensi terhadap waktu pada gambar 5-7 diperoleh dari data hasil pengujian pada 5 aki dengan persentase belimbing wuluh dan kulit pisang 90\%: 10\%. Tegangan aki sebesar 12 VDC. Kemudian aki dirangkai dengan inverter, tegangan aki menurun menjadi 7,8 VDC dengan arus perjam aki 0,08 A dan energi perjam 0,624 Wh. Output inverter $220 \mathrm{~V}$ dibebani dengan resistor $75 \Omega$, menghasilkan tegangan output inverter 1,4 VAC, arus perjam $0,019 \mathrm{~A}$, energi perjam $0,026 \mathrm{Wh}$ dan nilai efisiensi 4,263\%.

Nilai tegangan dan arus masuk inverter setiap percobaan menurun ketika masuk inverter setiap jamnya sehingga nilai output tegangan, energi perjam dan efisiensi tidak dapat dicapai. Hal ini disebabkan nilai hambatan pada inverter yang besar.

\section{KESIMPULAN}

Dari hasil analisa tugas akhir ini, maka dapat disimpulkan bahwa:

- Pengujian 2 aki menggunakan cairan belimbing wuluh dan kulit pisang dengan perbandingan 90\% : $10 \%$ menghasilkan energi sebesar 3,55 Wh, lama nyala lampu terang 30 menit dan mengalami redup selama 660 menit. Hal ini disebabkan oleh transfer elektron dari ion elektrolit yang baik.

- Hasil praktik dan teori untuk penyalaan lampu tidak sesuai. Hal ini disebabkan oleh cairan elektrolit dari buah belimbing wuluh dan kulit pisang yang mengalami perubahan, elektroda dalam cairan mengalami perubahan, elektrolit menguap, sebagian elektroda tidak tercelup elektrolit, beban yang tinggi dan sambungan yang kotor.

- Pengujian inverter 5 box aki dengan tegangan masukan 12 VDC pada aki menghasilkan tegangan keluaran 1,4 VAC dengan beban 75 Ohm. Nilai tegangan keluaran AC tidak sesuai yang diharapkan, hal ini disebabkan oleh hambatan yang terlalu besar pada inverter dan adanya rugi-rugi daya di box aki sebelum inverter dan setelah inverter.

- Aki hasil pemanfaatan campuran buah belimbing wuluh dan kulit pisang dengan menggunakan elektroda seng galvanis $(\mathrm{Zn})$ dan tembaga $(\mathrm{Cu})$ tidak dapat dijadikan pengganti asam sulfat $\left(\mathrm{H}_{2} \mathrm{SO}_{4}\right)$ karena elektrolit dari belimbing wuluh dan kulit pisang tidak bisa dilakukan charge (pengisian) namun dapat menjadi alternatif pengganti cairan elektrolit pada aki.

\section{DAFTAR PUSTAKA}

Ahmad, Hiskia. 1992. Elektrokimia dan Kinetika Kimia. PT Citra Aditya Bakti. Bandung.
Ahmad, Hiskia. 1993. Penuntun Dasar-dasar Praktikum Kimia. Direktorat. Jenderal Pendidikan Tinggi Proyek Pembinaan Tenaga Kependidikan Pendidikan Tinggi. Departemen Pendidikan dan Kebudayaan.

American Galvanizer Association. 2008. Zink Metal Properties.

Arban. 2016. Pembuatan Larutan Aki dengan Memanfaatkan Campuran Buah Belimbing Wuluh ( Averrhoa blimbi L.) da Jeruk Nipis (Citrus aurantifolia S.) Sebagai alternative Pengganti Elektrolit Cairan Asam Sulfat $\left(\mathrm{H}_{2} \mathrm{SO}_{4}\right)$. Politeknik Negeri Semarang.

B. G. Wollard. 1999. Elektronika Praktis. PT: Pradnya Pramita. Jakarta.

Bawotong, Vike Tiffani. Tanpa tahun. Rancang Bangun Uninterruptible Power Supply Menggunakan Tampilan LCD Berbasis Mikrokontroler. Manado.

Bird,T. 1993. Kimia Fisik untuk Universitas. PT Gramedia Pustaka Utama. Jakarta.

Chengel, A. Yunus and Boles, A. Michael. 2002. Thermodynamics an Engineering Approach, Fourth Edition. Mc Graw-Hill. New York.

C, Douglas.1998. Physics (Principles with Applications), Fifth Edition, Prentice-Hall International, Inc. Translate in Indonesia Language by Yuhilza Hanum. 2001.

Dalimartha, S. 2005. Ramuan Tradisonal Untuk

Pengobatan Diabetes Mellitus.

Jakarta: Penebar Swadaya. Bogor.

Dogra, S.K. 1990. Kimia Fisik dan Soal-Soal. Jakarta: Universitas Indonesia.

Herlih. 1993. Pengaruh Air Perasan Belimbing Wuluh (Averrhoa blimbi Linn) terhadap Kadar Kolesterol Serum Darah Tikus Putih. Skripsi Fakultas Farmasi, Universitas Gadjah Mada Yogyakarta.

Iptek. $2007 . \quad$ Belimbing Asam. http://www.iptek.net.id/ind/pd tanobat/view.

Jamal, N.A. 2008. Larutan Elektrolit dan Non Elektrolit Modul Kima Kelas X (Sepuluh). http://www.dikmenum.co.id.

Kartawidjaja, Rumeksa. E dan Abdurrochman. 2008. Prosiding Seminar Nasional Sains dan TeknologiII 2008. Universitas Lampung. Lampung.

Lindstrom. (Tanpa tahun). The Electric Fruits.

Orwa. 2009. Averrhoa blimbi L. Agroforestry Database 4.0 dalam penelitian

Wikanta, Wiwi. 2011. Pengaruh Penambahan Belimbing Wuluh (Averrhoa blimbi L.) dan Perebusan terhadap Residu Formalin dan Profil Protein Udang Putih (Letapenaeusa vannamei) Berformalin serta Pemanfaatannya sebagai Sumber Pendidikan Gizi dan Keamanan 
Pangan pada Masyarakat. Pasca Sarjana FK UB, Surabaya.

PT Carita Boat Indonesia. Pembangunan Kapal Fiberglass di PT Carita Boat Indonesia. 2010. Jakarta. UPN Veteran Jakarta.

Riyanto, Bambang. 2011. Eektrolit Baterai dari Polimer Chitosan.

http://bambangriyanto.staff.ipb.ac.id/category/apl ikasi-modern-chtosan/_pada tanggal 28 Februari 2018.

Seran. 2015. Larutan Elektrolit dan Non Elektrolit. http://chemistry for peace not for war/index.html.

Sunanto. 2010. Cara Mudah Menghasilkan Listrik dari Buah Belimbing. http://radensomad.com/caramudah-menghasilkan-listrik-dari-buah.html.

[14 Mei 2012 pukul 08.06].

Uriana. 2015. Analisis Pengaruh Tingkat Keasaman Limbah Kulit Pisang pada Karbon Penggantian Batu Baterai. Politeknik Negeri Semarang.

Wong, K.C, and Wong, S.N. 1995. Volatile Constituents of Averrhoa blimbi $L$ Fruit. http://www.fao.org/agis/search/display.do:jsessio nid=6CA568915012C8FE790C6DEAD0375A?f $=/ 1997 / \mathrm{v} 2305 / \mathrm{US} 9632171 . x \mathrm{ml} ; \mathrm{US} 963217171$. 02 April 2012.

Z. Zainuddin. 2007. Analisis Rangkaian Edisi Kedua. Graha Ilmu. Yogyakarta.

Zakaria, Z. A., H. Zaiton, E.F.P. Henie, A.M. Mat Jais and E. N. H. Engku Zainuddin. 2007. In Vitro Antibacterial Activity of Averrhoa blimbi L., Leaves and Fruits Extracts. Int. Journal of Tropical Medicine. 